\title{
The complete chloroplast genome sequence of Gossypium hirsutum: organization and phylogenetic relationships to other angiosperms Seung-Bum Lee ${ }^{1}$, Charalambos Kaittanis ${ }^{1}$, Robert K Jansen ${ }^{2}$, Jessica B Hostetler ${ }^{3}$, Luke J Tallon ${ }^{3}$, Christopher D Town ${ }^{3}$ and Henry Daniell*1
}

Address: ${ }^{1}$ Dept. of Molecular Biology \& Microbiology, University of Central Florida, Biomolecular Science, Building \#20, Orlando, FL $32816-$ 2364, USA, 2Section of Integrative Biology and Institute of Cellular and Molecular Biology, Patterson Laboratories 141, University of Texas, Austin, TX 78712, USA and ${ }^{3}$ The Institute for Genomic Research, 9712 Medical Center Drive, Rockville, MD 20850, USA

Email: Seung-Bum Lee - sbumlee@mail.ucf.edu; Charalambos Kaittanis - daniell@mail.ucf.edu; Robert K Jansen - jansen@mail.utexas.edu; Jessica B Hostetler - cdtown@tigr.ORG; Luke J Tallon - cdtown@tigr.ORG; Christopher D Town - cdtown@tigr.ORG;

Henry Daniell* - daniell@mail.ucf.edu

* Corresponding author

Published: 23 March 2006

BMC Genomics 2006, 7:61 doi:10.1186/|47|-2|64-7-6|

This article is available from: http://www.biomedcentral.com/|47/-2/64/7/6I

(c) 2006 Lee et al; licensee BioMed Central Ltd.

This is an Open Access article distributed under the terms of the Creative Commons Attribution License (http://creativecommons.org/licenses/by/2.0), which permits unrestricted use, distribution, and reproduction in any medium, provided the original work is properly cited.

\begin{abstract}
Background: Cotton (Gossypium hirsutum) is the most important fiber crop grown in 90 countries. In 2004-2005, US farmers planted $79 \%$ of the 5.7-million hectares of nuclear transgenic cotton. Unfortunately, genetically modified cotton has the potential to hybridize with other cultivated and wild relatives, resulting in geographical restrictions to cultivation. However, chloroplast genetic engineering offers the possibility of containment because of maternal inheritance of transgenes. The complete chloroplast genome of cotton provides essential information required for genetic engineering. In addition, the sequence data were used to assess phylogenetic relationships among the major clades of rosids using cotton and 25 other completely sequenced angiosperm chloroplast genomes.
\end{abstract}

Results: The complete cotton chloroplast genome is 160,30 I bp in length, with II 2 unique genes and 19 duplicated genes within the IR, containing a total of I 3 I genes. There are four ribosomal RNAs, 30 distinct tRNA genes and 17 intron-containing genes. The gene order in cotton is identical to that of tobacco but lacks rpl22 and infA. There are 30 direct and 24 inverted repeats 30 bp or longer with a sequence identity $\geq 90 \%$. Most of the direct repeats are within intergenic spacer regions, introns and a 72 bp-long direct repeat is within the $p s a A$ and $p s a B$ genes. Comparison of protein coding sequences with expressed sequence tags (ESTs) revealed nucleotide substitutions resulting in amino acid changes in $n d h C, r p / 23, r p / 20$, rps 3 and clpP. Phylogenetic analysis of a data set including 61 protein-coding genes using both maximum likelihood and maximum parsimony were performed for 28 taxa, including cotton and five other angiosperm chloroplast genomes that were not included in any previous phylogenies.

Conclusion: Cotton chloroplast genome lacks rpl22 and infA and contains a number of dispersed direct and inverted repeats. RNA editing resulted in amino acid changes with significant impact on their hydropathy. Phylogenetic analysis provides strong support for the position of cotton in the Malvales in the eurosids II clade sister to Arabidopsis in the Brassicales. Furthermore, there is strong support for the placement of the Myrtales sister to the eurosid I clade, although expanded taxon sampling is needed to further test this relationship. 


\section{Background}

The chloroplast is the site of photosynthesis, where light energy in photons is converted into chemical bond energy, via redox reactions, including inorganic carbon fixation at Calvin's cycle, finally yielding energy-rich carbohydrate molecules. Therefore, apart from the antennae, photosystem I and II complexes, which are found in the thylakoid membrane, the chloroplast contains the entire enzymatic machinery for carbohydrate biosynthesis in the stroma. Anabolic pathways such as protein, fatty acid, vitamin, and pigment biosynthesis take place in the chloroplast as well, indicating the organelle's ability to synthesize complex molecules. The chloroplast genome maintains a highly conserved organization [1,2] with most land plant genomes composed of a single circular chromosome with a quadripartite structure that includes two copies of an inverted repeat (IR) that separate the large and small single copy regions (LSC and SSC) [3]. The recent surge of interest in sequencing chloroplast genomes has provided a plethora of information on the organization and evolution of these genomes and new data for reconstructing phylogenetic relationships [2].

Chloroplast genetic engineering offers numerous advantages, including a high-level of transgene expression [4], multi-gene engineering in a single transformation event [4-7], transgene containment via maternal inheritance [811] or cytoplasmic male sterility [12], lack of gene silencing $[4,13]$, position effect due to site specific transgene integration [14], and pleiotropic effects due to sub-cellular compartmentalization of transgene products $[13,15,16]$. Apart from expressing therapeutic agents, biopolymers, or transgenes to confer agronomic traits, plastid genetic engineering has been used to study plastid biogenesis and function, revealing mechanisms of plastid DNA replication origins, intron maturases, translation elements and proteolysis, import of proteins and several other processes [18]. Despite the potential of chloroplast genetic engineering, this technology has only recently been extended to the major crops, including soybean [19], carrot [20] and cotton [21], via somatic embryogenesis, achieving transgene expression in non-green plastids [22]. All other previous studies focused on direct organogenesis by bombardment of leaves containing mature green chloroplasts [22]. Lack of complete chloroplast genome sequences to provide $100 \%$ homologous species-specific chloroplast transformation vectors, containing suitable selectable markers and endogenous regulatory elements, is one of the major limitations to extend this concept to other useful crops [22,23].

The need for sequencing the cotton plastome is obvious, when considering its annual retail value of about $\$ 120$ billion, making it America's most value-added crop. This is justified by the fact that cotton is the single most impor- tant textile fiber grown in 90 countries; the US accounts for $21 \%$ of the total world fiber production. In 20042005 , US farmers planted $79 \%$ of the 5.7 -million hectares of nuclear transgenic cotton. Upland cotton, Gossypium hirsutum, has the potential to hybridize with G. tomentosum, feral populations of G. hirsutum, and G. hirsutum/G. barbadense [21]. Therefore, geographical restrictions in planting genetically modified cotton are in place because of reports of pollen dispersal from transgenic cotton plants [25]. Chloroplast genetic engineering could minimize transgene escape because of maternal inheritance of transgenes [8-11]. In addition, other failsafe mechanisms, including cytoplasmic male sterility could be employed to contain transgenes [12].

The examination of phylogenetic relationships among angiosperms has received considerable attention during the past decade [reviewed in [26]]. Although there is considerable consensus about the circumscription and relationships among many of the major clades, most molecular phylogenetic analyses have examined numerous taxa but have relied on only a few gene sequences. Completely sequenced chloroplast genomes provide a rich source of nucleotide sequence data that can be used to address phylogenetic questions. Several recent studies have attempted to use completely sequenced genomes to resolve the identification of the basal lineages of flowering plants [27-29]. Use of many or all of the genes from the chloroplast genome provides many more characters for phylogeny reconstruction in comparison with previous studies that have relied on only a few genes. However, the limited number of available whole chloroplast genome sequences can result in misleading estimates of relationship $[27,30]$. This problem can be overcome as more complete chloroplast genome sequences become available.

In this article, we present the complete sequence of the chloroplast genome of upland cotton, Gossypium hirsutum. One goal of this paper is to examine gene content and gene order, and determine the distribution and location of repeated sequences. Secondly, the RNA editing sites in the cotton chloroplast genome are identified and examined, by comparing the DNA sequences with available expressed sequence tag (EST) sequences, because RNA editing plays a major role in several lineages of plants [31,32]. Lastly, protein-coding sequences from 61 genes are used to estimate phylogenetic relationships of cotton with 25 other angiosperms.

\section{Results \\ Size, gene content, order and organization of the cotton chloroplast genome}

Cotton complete chloroplast genome is $160,301 \mathrm{bp}$ in length (Fig. 1), and includes a pair of inverted repeats 25,608 bp long, separated by a small and a large single 


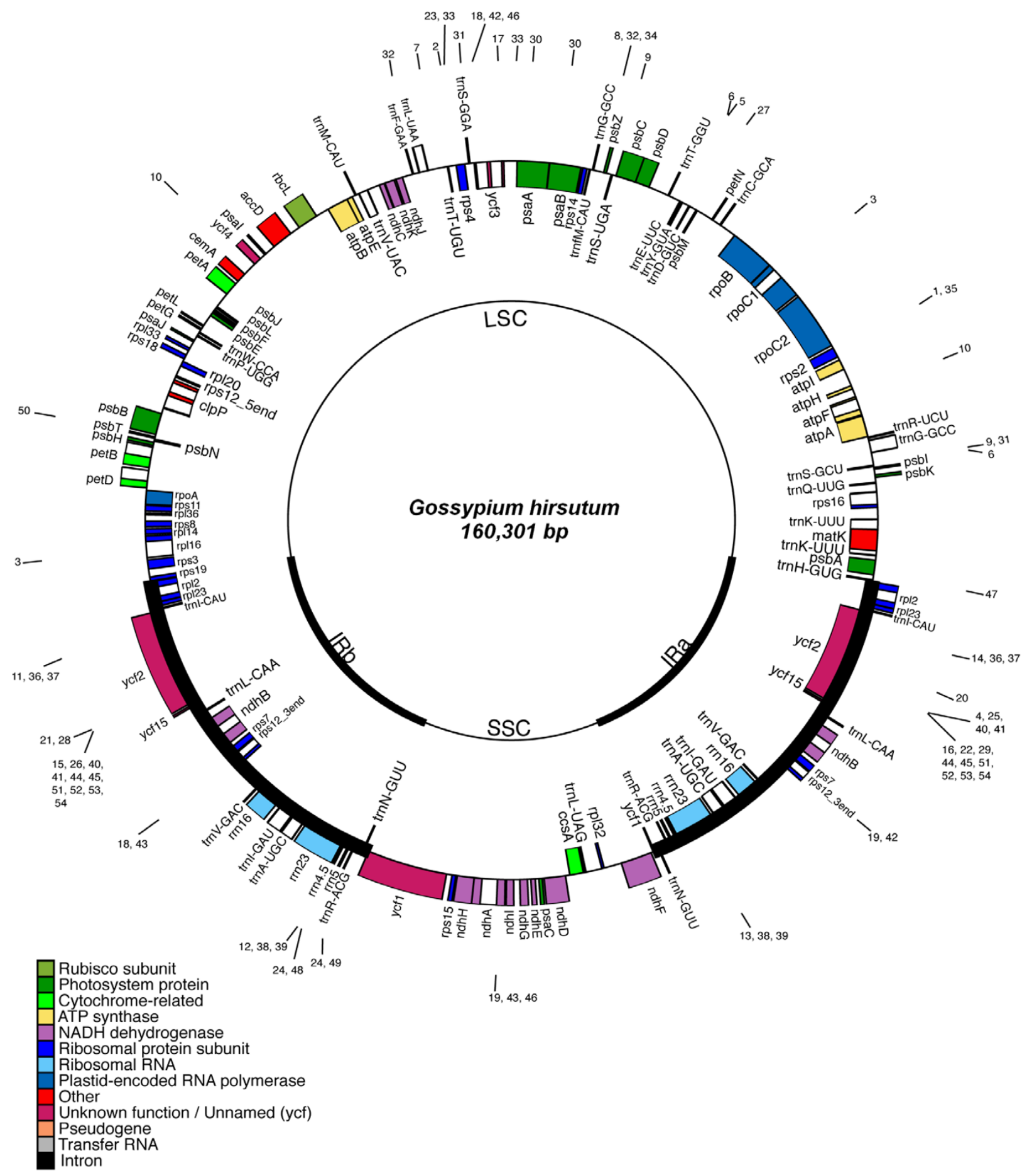

Figure I

Gene map of the Gossypium hirsutum chloroplast genome. The thick lines indicate the extent of the inverted repeats (IRa and IRb), which separate the genome into small (SSC) and large (LSC) single copy regions. Genes on the outside of the map are transcribed in the clockwise direction and genes on the inside of the map are transcribed in the counterclockwise direction. Numbered lines around the map indicate the location of repeated sequences found in the cotton genome (see Table I for details). The SSC region is in the reverse orientation relative to tobacco [80]. This does not reflect any differences in gene order for cotton but simply reflects the well-known phenomenon that the SSC exists in two orientations in chloroplast genomes [84]. 
copy region of 20,269 bp and 88,816 bp, respectively. There are 112 unique genes within the cotton chloroplast genome and 19 of these are duplicated in the IR, giving a total of 131 genes (Fig. 1). Furthermore, there are four ribosomal and 30 distinct tRNA genes; seven of the tRNA genes and all rRNA genes are duplicated within the IR. There are 17 intron-containing genes, 15 of which contain one intron, whereas the remaining two have two introns. The gene order in the cotton plastid genome is identical to that of tobacco, but cotton lacks the rpl22 and infA genes. Overall, genomic content is $37.25 \%$ GC and $62.75 \%$ AT, where $56.46 \%$ of the genome corresponds to protein coding genes and $43.54 \%$ to non-coding regions, including introns and intergenic spacers.

\section{Repeat structure}

Repeat analysis identified 30 direct and 24 inverted repeats $30 \mathrm{bp}$ or longer with a sequence identity of at least 90\% (Fig. 2 and Table 1). Twenty-three direct and 15 inverted repeats are 30 to $40 \mathrm{bp}$ long, and the longest direct repeat is $72 \mathrm{bp}$. Most of the direct repeats are within intergenic spacer regions, intron sequences and $y c f 2$, an essential hypothetical chloroplast gene [33]. Interestingly, a 72 bp-long direct repeat was found in the $p s a A$ and $p s a B$ genes, whereas a 34-bp forward repeat was within the rrn23 gene, and a shorter, 32 bp-long direct repeat was identified in two serine transfer-RNA(trnS) genes that recognize different codons; trnS-GCU and trnS-UGA.

\section{RNA editing}

Comparison of the nucleotide sequences of protein coding genes and EST sequences retrieved from GenBank

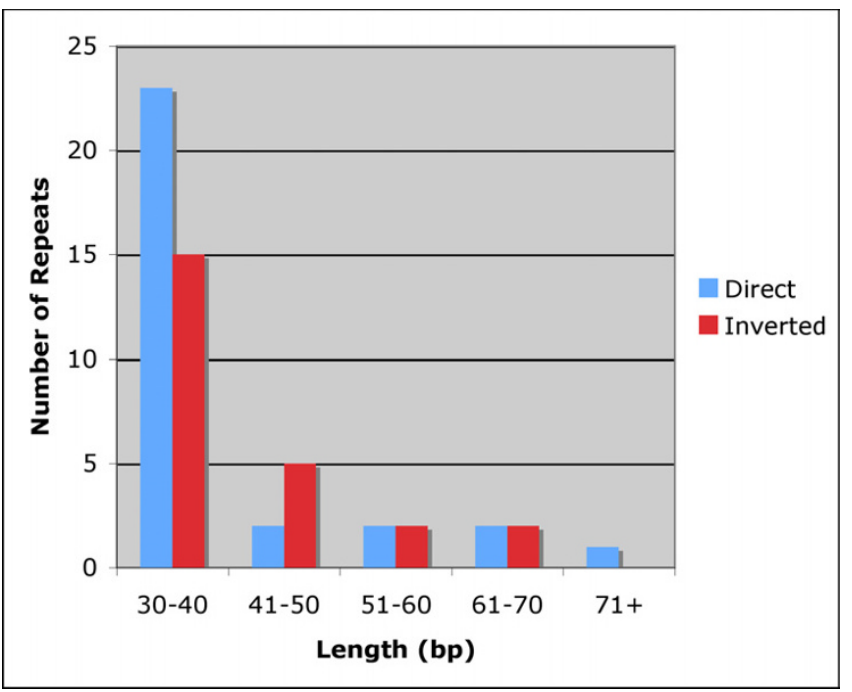

Figure 2

Histogram showing the number of repeated sequences $\geq 30$ bp long with a sequence identity $\geq 90 \%$ in the cotton chloroplast genome. revealed that $r p s 16, r p l 2, r p o C 2, r p s 4$ and $y c f 1$ have $100 \%$ sequence identity with their respective ESTs (data not shown). Eleven non-synonymous nucleotide substitutions, resulting in a total of nine amino acid changes, were identified within $n d h C, r p l 23, r p l 20, r p s 3$ and $c l p P$ compared to respective ESTs, although their sequence identity was above $98 \%$ (Table 2). Surprisingly, there were no synonymous substitutions. All of the five aforementioned genes experienced one or two nucleotide substitutions, apart from the protease-encoding $c l p P$, which had five variable sites. Lastly, in all but $r p l 23$, the nucleotide substitutions had an impact on the hydropathy of the amino acid because they changed the amino acids from aliphatic to hydrophilic, and vice versa.

\section{Phylogenetic analysis}

The data matrix for phylogenetic analyses included 61 protein-coding genes for 28 taxa (Table 3), including 26 angiosperms and two gymnosperm outgroups (Pinus and Ginkgo). The data set comprised 45,573 nucleotide positions but when the gaps were excluded there were 39,624 characters. Maximum Parsimony (MP) analyses resulted in a single, fully resolved tree with a length of 49,957 , a consistency index of 0.46 (excluding uninformative characters) and a retention index of 0.62 (Fig. 3). Bootstrap analyses indicated that 24 of the 26 nodes were supported by values $\geq 95 \%$ with 19 of these with bootstrap values of $100 \%$. Maximum Likelihood (ML) analysis resulted in a tree with a $-\operatorname{lnL}=311251.33$. The ML and MP trees had identical topologies so only the MP tree is shown in Figure 3.

Several major groups were supported within angiosperms and these groups are generally in agreement with recent classifications [26]. The most basal lineage was Amborella followed by the Nymphaeales. The next branch included Calycanthus, the sole representative of magnoliids in the data set. This was followed by a strongly supported clade of monocots, represented by members of three different orders (Acorales, Asparagales, and Poales). The monocots were then sister to the eudicots with the Ranunculales forming the earliest diverging eudicot clade. Within the core eudicots there were two major clades, one including the rosids and the second including the Caryophyllales sister to asterids. Within the rosid clade there were two major groups, the eurosids II and a group that included the Myrtales sister to the eurosids I. Gossypium in the Malvales was sister to Arabidopsis in the Brassicales.

\section{Discussion}

\section{Implications for integration of transgenes}

We have recently demonstrated stable transformation of the cotton plastid genome and maternal inheritance of transgenes via somatic embryogenesis [21]. In contrast to previous reports on integrating foreign genes in tomato 


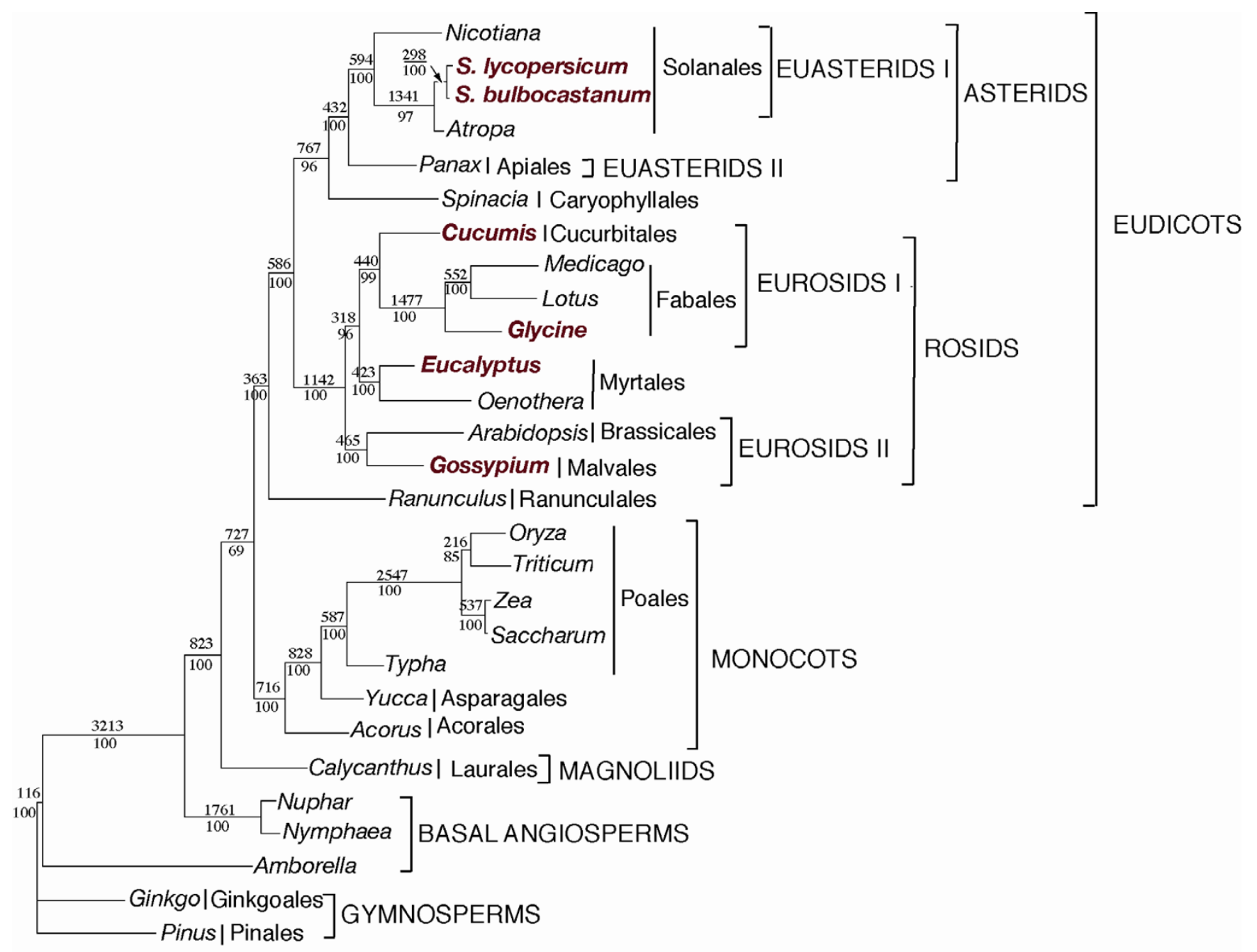

1000 changes

\section{Figure 3}

Parsimony tree based on $6 \mathrm{I}$ chloroplast protein-coding genes. The tree has a length of 49,957 , a consistency index of 0.46 (excluding uninformative characters) and a retention index of 0.6 . Numbers above node indicate number of changes along each branch and numbers below nodes are bootstrap support values. Taxa in red are those which have not appeared in any previous phylogenetic studies using $6 \mathrm{I}$ genes from complete chloroplast genome sequences. Ordinal and higher level group names follow APG II [85]. The maximum likelihood tree has the same topology but is not shown.

and potato chloroplast genomes using tobacco flanking sequences that do not have $100 \%$ sequence identity $[24,34,35]$, the cotton plastid transformation vector was constructed using the PCR-amplified native cotton 16S/ trnI-trnA/23S sequence. However, regulatory sequences used in the cotton plastid transformation were derived from tobacco or other heterologous sequences. With the availability of the entire cotton chloroplast genome sequence, it should now be possible to utilize endogenous regulatory sequences. Species-specific vectors should be effective for plastid transformation, especially in recalcitrant plants, because of transgene integration using flank- ing sequences with $100 \%$ sequence identity and endogenous promoters, 5' \& 3'untranslated regions, thereby enhancing transcription and translation of transgenes. Also, the complete chloroplast genome provides the option of transgene integration into transcriptionally silent, active or read-through spacer regions for optimal transgene integration.

Thus far, transgenes conferring several useful agronomic traits, including insect $[4,36,37]$, herbicide $[8,38]$, and disease resistance [39], drought [13] and salt tolerance [20], phytoremediation [5], as well as cytoplasmic male 
Table I: Location of identified repeats in the cotton plastid genome. Table includes repeats at least 30 bp in size, with a sequence identity greater than or equal to $90 \%$. IGS = Intergenic spacer. See Fig. I for location of repeats on the gene map.

\begin{tabular}{|c|c|c|}
\hline Repeat Number & Size (bp) & Location \\
\hline 1 & 30 & IGS \\
\hline 2 & 30 & IGS \\
\hline 3 & 30 & rpoCl intron, $r p / l 6$ intron \\
\hline 4 & 30 & $y c f 2$ \\
\hline 5 & 31 & IGS \\
\hline 6 & 32 & psbl (5 bp) - IGS, IGS \\
\hline 7 & 32 & IGS \\
\hline 8 & 32 & IGS \\
\hline 9 & 32 & IGS (4 bp) - trnS-GCU, IGS (4 bp) - trnS-UGA \\
\hline 10 & 32 & IGS \\
\hline 11 & 34 & $y c f 2$ \\
\hline 12 & 34 & IGS \\
\hline 13 & 34 & rrn23 exon \\
\hline 14 & 34 & ycf2 \\
\hline 15 & 34 & $y c f 2$ \\
\hline 16 & 34 & ycf2 \\
\hline 17 & 35 & ycß3 intron \\
\hline 18 & 36 & yç3 intron, IGS \\
\hline 19 & 38 & ndhA intron, $r p s / 2$ 3end intron \\
\hline 20 & 38 & $y c f 2$ \\
\hline 21 & 38 & ycf2 \\
\hline 22 & 38 & ycf2 \\
\hline 23 & 40 & IGS \\
\hline 24 & 43 & IGS \\
\hline 25 & 47 & ycf2 \\
\hline 26 & 52 & $y c f 2$ \\
\hline 27 & 58 & IGS \\
\hline 28 & 64 & $y c f 2$ \\
\hline 29 & 64 & ycf2 \\
\hline 30 & 72 & psaA exon, psaB exon \\
\hline 31 & 30 & IGS (2 bp) - trnS-GCU, trnS-GGA \\
\hline 32 & 30 & IGS \\
\hline 33 & 30 & IGS \\
\hline 34 & 31 & IGS \\
\hline 35 & 34 & IGS \\
\hline 36 & 34 & ycf2 \\
\hline 37 & 34 & $y c f 2$ \\
\hline 38 & 34 & IGS \\
\hline 39 & 34 & IGS \\
\hline 40 & 34 & $y c f 2$ \\
\hline 41 & 34 & ycf2 \\
\hline 42 & 36 & yç3 intron, IGS \\
\hline 43 & 38 & IGS, ndhA intron \\
\hline 44 & 38 & $y c f 2$ \\
\hline 45 & 38 & $y c f 2$ \\
\hline 46 & 41 & $y c ґ 3$ intron, $n d h A$ intron \\
\hline 47 & 41 & IGS \\
\hline 48 & 43 & IGS \\
\hline 49 & 43 & IGS \\
\hline 50 & 48 & IGS \\
\hline 51 & 52 & $y c f 2$ \\
\hline 52 & 52 & ycf2 \\
\hline 53 & 64 & $y c f 2$ \\
\hline 54 & 64 & ycf2 \\
\hline
\end{tabular}


Table 2: Differences observed by comparison of cotton chloroplast genome sequences with EST sequences obtained by BLAST searches of GenBank.

\begin{tabular}{|c|c|c|c|c|c|c|}
\hline Gene & Gene size (bp) & $\begin{array}{c}\text { Sequence ana- } \\
\text { lyzed }^{\text {a }}\end{array}$ & $\begin{array}{c}\text { Number of } \\
\text { variable sites }\end{array}$ & Variation type & Position(s) ${ }^{b}$ & $\begin{array}{c}\text { Amino acid } \\
\text { change }\end{array}$ \\
\hline \multirow[t]{5}{*}{$c l p P$} & 591 & $228-537$ & 5 & A-G & 523 & $M-A$ \\
\hline & & & & $\mathrm{T}-\mathrm{C}$ & 524 & \\
\hline & & & & T-A & 528 & I-M \\
\hline & & & & T-G & 531 & G-S \\
\hline & & & & G-A & 532 & \\
\hline ndhC & 363 & $76-363$ & 1 & $\mathrm{~T}-\mathrm{C}$ & 323 & L-S \\
\hline \multirow[t]{2}{*}{$r p / 20$} & 354 & $\mathrm{I}-354$ & 2 & $A-G$ & 263 & $K-R$ \\
\hline & & & & $\mathrm{C}-\mathrm{U}$ & 308 & S-L \\
\hline$r p / 23$ & 282 & $85-282$ & 1 & $\mathrm{C}-\mathrm{U}$ & 89 & S-L \\
\hline \multirow[t]{2}{*}{ rps3 } & 657 & $274-657$ & 2 & T-G & 275 & $L-R$ \\
\hline & & & & $A-C$ & 302 & $\mathrm{~K}-\mathrm{T}$ \\
\hline
\end{tabular}

aSequence analyzed coordinates based on the gene sequence, considering the first base of the initiation codon as bp I. bVariable position is given in reference to the first base of the initiation codon of the gene sequence.

sterility [12], have been stably integrated and expressed, via the tobacco chloroplast genome. Using the chloroplast as a bioreactor, vaccine antigens $[15,40-42]$, human therapeutic proteins [17,43-45], industrial enzymes [46] and

Table 3: Taxa included phylogenetic analyses with GenBank accession numbers and references. Taxa in bold are those which have not appeared in any previous phylogenetic studies using $6 \mathrm{I}$ genes from complete chloroplast genome sequences.

\begin{tabular}{|c|c|c|}
\hline Taxon & GenBank Accession Numbers & Reference \\
\hline \multicolumn{3}{|l|}{ Gymnosperms -Outgroups } \\
\hline Pinus thunbergii & NC 001631 & Wakasugi et al. 1994 [72] \\
\hline Ginkgo biloba & DQ069337-DQ069702 & Leebens-Mack et al 2005 [27] \\
\hline \multicolumn{3}{|l|}{ Basal Angiosperms } \\
\hline Amborella trichopoda & NC 005086 & Goremykin et al. 2003 [29] \\
\hline Nuphar advena & DQ069337-DQ069702 & Leebens-Mack et al 2005 [27] \\
\hline Nymphaea alba & NC 006050 & Goremykin et al. 2004 [28] \\
\hline \multicolumn{3}{|l|}{ Monocots } \\
\hline Acorus americanus & DQ069337-DQ069702 & Leebens-Mack et al 2005 [27] \\
\hline Oryza sativa & NC 001320 & Hiratsuka et al. 1989 [73] \\
\hline Saccharum officinarum & NC 006084 & Asano et al. 2004 [74] \\
\hline Triticum aestivum & NC 002762 & Ikeo and Ogihara, unpublished \\
\hline Typha latifolia & DQ069337-DQ069702 & Leebens-Mack et al 2005 [27] \\
\hline Yucca schidigera & DQ069337-DQ069702 & Leebens-Mack et al 2005 [27] \\
\hline Zea mays & NC 001666 & Maier et al. 1995 [75] \\
\hline \multicolumn{3}{|l|}{ Magnoliids } \\
\hline Calycanthus floridus & NC 004993 & Goremykin et al. 2003 [76] \\
\hline \multicolumn{3}{|l|}{ Eudicots } \\
\hline Arabidopsis thalliana & NC 000932 & Sato et al. 1999 [77] \\
\hline Atropa belladonna & NC 004561 & Schmitz-Linneweber et al. 2002 [53] \\
\hline Cucumis sativus & NC 007144 & Plader et al. unpublished \\
\hline Eucalyptus globulus & AY780259 & Steane 2005 [78] \\
\hline Glycine max & $\overline{\mathrm{DQ} 317523}$ & Saski et al. 2005 [3] \\
\hline Gossypium hirsutum & $\overline{\mathrm{DQ} 345959}$ & Current study \\
\hline Lotus corniculatus & NC 002694 & Kato et al. 2000 [79] \\
\hline Medicago truncatula & $\overline{N C \quad 003119}$ & Lin et al., unpublished \\
\hline Nicotiana tabacum & NC 001879 & Shinozaki et al. 1986 [80] \\
\hline Oenothera elata & NC 002693 & Hupfer et al. $2000[81]$ \\
\hline Panax schinseng & NC 006290 & Kim and Lee 2004 [82] \\
\hline Ranunculus macranthus & DQ069337-DQ069702 & Leebens-Mack et al 2005 [27] \\
\hline Solanum lycopersicum & $\overline{\mathrm{DQ} 347959}$ & Daniell et al. in press \\
\hline Solanum bulboscastanum & DQ347958 & Daniell et al. in press \\
\hline Spinacia oleracea & NC 002202 & Schmitz-Linneweber et al. 200I [83] \\
\hline
\end{tabular}


biomaterials $[6,47,48]$ have been produced successfully in an environmental friendly way. Although many successful examples of plastid engineering in tobacco have set a solid foundation for various future applications, this technology has not been extended to many of the major crops, primarily due to the lack of complete chloroplast genome sequences and challenges in achieving homoplasmy in recalcitrant crops.

\section{Evolutionary implications}

Other than the IR, repeated sequences are generally considered to be uncommon in chloroplast genomes [1]. Furthermore, previous studies based on both filter hybridization and DNA sequencing have indicated that dispersed repeats are found more commonly in genomes that have experienced changes in genome organization $[49,56]$, especially in highly rearranged algal genomes $[51,52]$. The most extensive examination of repeat structure in angiosperms was performed in legumes [3], which do have a single inversion and in some taxa a loss of one copy of the IR. These repeat analyses identified a substantial number highly conserved repeats $\geq 30$ bp with a sequence identity of $\geq 90 \%$. Many of these repeats were located in intergenic spacer regions and introns, with several located in the coding regions of $p s a A, p s a B$, and $y c f 2$. Our examination of repeats in the cotton chloroplast genome (Table 1, Fig. 2) identified similar numbers of repeats as in legumes [3], and these are also located mostly in intergenic spacer regions and introns. Repeats in coding regions of cotton are located in the same genes as in legumes. Overall, it appears that dispersed repeats are very common in angiosperm chloroplast genomes, even in genomes that have not experienced rearrangements. Future comparative studies are needed to determine the functional and evolutionary role these repeats may play in chloroplast genomes.

DNA and EST sequence comparisons identified many nucleotide substitutions resulting in amino acid changes. Based on previous studies of Atropa [53] and tobacco [54], posttranscriptional RNA editing events result predominantly in C-to-U edits. However, analysis of the cotton genome and EST sequences indicates that only two of the eleven differences were $\mathrm{C}$-to-U changes, suggesting that most of these changes are not mRNA edits but may simply represent intra-species polymorphisms. Evolutionary loss of RNA editing sites has been previously observed and could possibly be due to a decrease in the effect of RNAediting enzymes [31]. Additionally, conversions other than C-to-U in cotton, as well as other crops, suggest that chloroplast genomes may be accumulating considerable amounts of nucleotide substitutions, where some genes might accrue more alterations than others, such as the pet $L$ and $n d h$ genes that have a high frequency of RNA editing [55]. Therefore, despite the plastome's high conservation, variations occur post-transcriptionally, promoting translational efficiency due to transcript-protein complex binding and/or changes in the chloroplast microenvironment, like redox potential or light intensity $[56,57]$.

The phylogeny based on 61 protein-coding genes for 28 angiosperms is congruent with relationships suggested in previous studies [summarized in [26]]. There is strong support for the monophyly all of the major clades of angiosperms, including monocots, eudicots, rosids, asterids, eurosids I, eurosids II, asterids I and asterid II. Our phylogenetic analyses have greatly expanded the taxon sampling of entire genomes because we included six genomes (in bold in Table 1 and Fig. 3) that have not been included in recently published phylogenies based on complete chloroplast genomes [27-29,58]. The sampling is particularly expanded in the rosids with four of the six genomes from this clade. Thus, we will focus our discussion of the phylogenetic implications of this expanded analysis on this group.

The rosid clade is very large and includes nearly 140 families representing almost one third of all angiosperms. The most recent phylogenies of this group [summarized in chapter 8 in [26]] indicate that there are seven major clades whose relationships still remain unresolved. Representatives of three of these major clades are included in our analyses, eurosids I, eurosids II, and Myrtales. The position of the Myrtales has been especially controversial with no clear resolution of the relationship of this order to other members of the rosids. Our 61 gene chloroplast phylogeny (Fig. 3) provides strong support for a sister relationship of the Myrtales with the eurosid I clade. A three-gene phylogeny of 560 angiosperms is congruent with our results [59], although support was very weak. However, a sister relationship between eurosids I and Myrtales is in conflict with two other recent phylogenies based on two chloroplast genes $(a t p B, r b c L)$, which placed the Myrtales sister to the eurosid II clade with weak support $[60,61]$. Although our results clearly favor a closer relationship of Myrtales to the eurosid I clade, expanded sampling of complete chloroplast genome sequences of rosids is needed to resolve this issue, especially since limited taxon sampling can lead to erroneous tree topologies $[27,30]$.

Our chloroplast phylogeny (Fig. 3) also supports the sister relationship between the orders Cucurbitales and Fabales, two of the four nitrogen fixing clades of eurosids I. Furthermore, the position of cotton, a member of the order Malvales, as sister to Arabidopsis in the Brassicales, is in agreement with recently phylogenies of the eurosid II clade [26]. 


\section{Conclusion}

Our complete sequence of the cotton chloroplast genome provides the needed information for expanding chloroplast genetic engineering to this important crop plant. Although genome organization of cotton is very similar to other unrearranged angiosperm chloroplast genomes, identification of disperse repeats and potential RNA editing sites provides new insights into the evolution of this genome. Finally, phylogenetic analyses of sequences of 61 protein-coding genes for 26 angiosperms suggests that the order Myrtales is sister to the eurosid I clade but denser sampling is needed to test this result rigorously.

\section{Methods}

\section{DNA isolation and amplification}

Gossypium hirsutum plants cv. Coker310FR were grown from seedlings in soil pots, until they were $1 \mathrm{~m}$ tall. Prior to DNA extraction, the plants were placed in the dark for two days to reduce the chloroplast starch levels. After that, $10 \mathrm{~g}$ of young leaf tissue was collected for cpDNA isolation based on the sucrose step gradient centrifugation method by Sandbrink et al [62]. Isolation was followed by whole chloroplast genome Rolling Circle Amplification (RCA), using the Repli-g RCA kit (Qiagen, Inc.) following the methods outlined in [63]. After incubation at $30^{\circ} \mathrm{C}$ for $16 \mathrm{hr}$, the reaction was terminated with 10 -minute incubation at $65^{\circ} \mathrm{C}$. Digestion of the RCA product with BstXI, EcoRI and HindIII allowed verification of successful RCA plastome amplification, as well as assessment of its quality, prior to DNA sequencing.

\section{DNA sequencing and genome assembly}

DNA was sheared by nebulization, size fractionated to 4$6 \mathrm{~kb}$, linker ligated and cloned into pHOS2, a TIGR medium copy vector. A total of 1619 good reads with an average length of 812 bases was generated during the random (1396 reads) and closure (223 reads) phases of sequencing. Sequences were assembled using TIGR assembler [64] and scaffolded using Bambus [65]. Sequence finishing included directed PCR to span gaps, directed primer walking on clones and transposon mediated sequencing of full clones to cover the entire genome and complete regions of low coverage and manual editing of sequences to resolve inconsistencies.

\section{Gene annotation}

The cotton genome was annotated using DOGMA [Dual Organellar GenoMe Annotator, [66]], after uploading a FASTA-formatted file of the complete plastid genome to the program's server. BLASTX and BLASTN searches, against a custom database of previously published plastid genomes, identified cotton's putative protein-coding genes, and tRNAs or rRNAs. For genes with low sequence identity, manual annotation was performed, after identifying the position of the start and stop codons, as well as the translated amino acid sequence, using the plastid/bacterial genetic code.

\section{Examination of repeat structure}

REPuter [67] was used to locate and count the direct (forward) and inverted (palindromic) repeats within the cotton chloroplast genome. For repeat identification, the following constraints were used: (i) minimum repeat size of $30 \mathrm{bp}$, and (ii) $90 \%$ or greater sequence identity, based on Hamming distance equal to $3 \mathrm{bp}$ [3]. Manual verification of the identified repeats was performed in EditSeq, while performing intragenomic blast search of the identified repeat sequence.

\section{Variation between coding sequences and cDNAs}

Each of the gene sequences from the cotton chloroplast genome was used to perform a BLAST search of expressed sequence tags (ESTs) from GenBank. The retrieved Gossypium hirsutum ESTs were aligned with the corresponding annotated gene using ClustalX [68], followed by screening for nucleotide and amino acid changes using Megalign and its' plastid/bacterial genetic code. Because of variation in the length between an EST and the related gene, the length of the analyzed sequence was recorded.

\section{Phylogenetic analysis}

The 61 genes included in the analyses of Goremykin et al. $[28,29]$ and Leebens-Mack et al. [27] were extracted from our new chloroplast genome sequences of cotton using the organellar genome annotation program DOGMA. [66]. The same set of 61 genes was extracted from chloroplast genome sequences of five other recently sequenced angiosperm chloroplast genomes, including tomato, potato, soybean, cucumber, and Eucalyptus (see Table 3 for complete list of genomes examined). In general, alignment of the DNA sequences was straightforward and simply involved removing gaps included in the data set because of the elimination of non-seed plants and adding the 61 genes for the new angiosperms to the aligned data matrix from Leebens-Mack et al. [27]. In some cases, small in frame insertions or deletions were required for correct alignment. For two genes, ccsA and matK, the DNA sequences were more divergent, requiring alignment using ClustalX [68] followed by manual adjustments.

Phylogenetic analyses using maximum parsimony (MP) and maximum likelihood (ML) were performed using PAUP* version 4.10 [69]. All phylogenetic analyses excluded gap regions. All MP searches were heuristic with 100 random addition replicates and TBR branch swapping with the Multrees option. The Hasegawa-KishinoYano (HKY; [70]) model of molecular evolution was used in $\mathrm{ML}$ analyses of the nucleotide sequences. ML analyses used TBR branch swapping with the Multrees option and one random addition replicate. Non-parametric bootstrap 
analyses [71] were performed for MP analyses with 1000 replicates with TBR branch swapping, one random addition replicate, and the Multrees option and for ML analyses with 100 replicates with NNI branch swapping, one random addition replicate, and the Multrees option.

\section{Abbreviations}

cPDNA, chloroplast DNA; IR inverted repeat; SSC, small single copy; LSC, large single copy, bp, base pair; ycf, hypothetical chloroplast reading frame; rrn, ribosomal RNA; MP, maximum parsimony; ML, maximum likelihood; EST, expressed sequence tag; cDNA, complementary DNA.

\section{Authors' contributions}

SBL isolated chloroplasts, performed RCA amplification of cpDNA, genome annotation, analysis and submission of data to the GenBank; CK performed the repeat analyses, comparisons of DNA and EST sequences, assisted with extraction \& alignment of DNA sequences for phylogenetic analyses and wrote a few sections of the first draft; JBH, LJT and CDT performed DNA sequencing and genome assembly; RKJ assisted with extracting and aligning DNA sequences, performed phylogenetic analyses, and wrote the phylogenetic portions of the manuscript; HD conceived and designed this study, interpreted data, wrote and revised several versions of this manuscript. All authors read and approved the final manuscript.

\section{Acknowledgements}

Investigations reported in this article were supported in part by grants from USDA 36 I I-2 1000-0 I7-00D to Henry Daniell and from NSF DEB 0120709 to Robert K. Jansen.

\section{References}

I. Palmer JD: Plastid chromosomes: structure and evolution. In The Molecular Biology of Plastids Edited by: Bogorad L, Vasil K. San Diego: Academic Press; 1991:5-53.

2. Raubeson LA, Jansen RK: Chloroplast genomes of plants. In Diversity and Evolution of Plants-Genotypic and Phenotypic Variation in Higher Plants Edited by: Henry $\mathrm{H}$. Wallingford: CABI Publishing; 2005:45-68.

3. Saski C, Lee S, Daniell H, Wood T, Tomkins J, Kim H-G, Jansen RK: Complete chloroplast genome sequence of Glycine max and comparative analyses with other legume genomes. Plt Mol Biol 2005, 59:309-322.

4. DeCosa B, Moar W, Lee SB, Miller M, Daniell H: Overexpression of the $B t$ cry2Aa2 operon in chloroplasts leads to formation of insecticidal crystals. Nat Biotechnol 200I, 9:7I-74.

5. Ruiz ON, Hussein H, Terry N, Daniell H: Phytoremediation of organomercurial compounds via chloroplast genetic engineering. Plt Phys 2003, 32:1344-I352.

6. Lossl A, Eibl C, Harloff HJ, Jung C, Koop HU: Polyester synthesis in transplastomic tobacco (Nicotiana tabacum L.): significant contents of polyhydroxybutyrate are associated with growth reduction. Plt Cell Rep 2003, 21:891-899.

7. Quesada-Vargas T, Ruiz ON, Daniell H: Characterization of heterologous multigene operons in transgenic chloroplasts: transcription, processing, translation. Plt Physiol 2005, 138: 1746-1762.

8. Daniell H, Datta R, Varma S, Gray S, Lee SB: Containment of herbicide resistance through genetic engineering of the chloroplast genome. Nat Biotechnol 1998, 16:345-348.
9. Scott SE, Wilkenson MJ: Low probability of chloroplast movement from oilseed rape (Brassica napus) into wild Brassica rapa. Nat Biotechnol 1999, I7:390-392.

10. Daniell $\mathrm{H}$ : Molecular strategies for gene containment in transgenic crops. Nat Biotechnol 2002, 20:581-586.

II. Hagemann R: The Sexual Inheritance of Plant Organelles. In Molecular Biology and Biotechnology of Plant Organelles Edited by: Daniell $\mathrm{H}$, Chase C. Dordrecht, The Netherlands: Springer Publishers; 2004:93-II3.

12. Ruiz ON, Daniell H: Engineering cytoplasmic male sterility via the chloroplast genome. Plt Physiol 2005, 138:1232-1246.

13. Lee SB, Kwon HB, Kwon SJ, Park SC, Jeong MJ, Han SE, Daniell H: Accumulation of trehalose within transgenic chloroplasts confers drought tolerance. Mol Breed 2003, I I: I-I3.

I4. Daniell H, Khan M, Allison L: Milestones in chloroplast genetic engineering: an environmentally friendly era in biotechnology. Trends Plt Sci 2002, 7:84-9I.

15. Daniell H, Lee SB, Panchal T, Wiebe PO: Expression of cholera toxin $B$ subunit gene and assembly as functional oligomers in transgenic tobacco chloroplasts. J Mol Biol 200 I, 3 I I: 100 I- 1009

16. Leelavathi S, Reddy VS: Chloroplast expression of His-tagged GUS-fusions: a general strategy to overproduce and purify foreign proteins using transplastomic plants as bioreactors. Mol Breed 2003, I I:49-58.

17. Daniell H, Carmona-Sanchez O, Burns BB: Chloroplast-derived vaccine antibodies, biopharmaceuticals, and edible vaccines in transgenic plants engineered via the chloroplast genome. In Molecular Farming Volume Chapter 8. Edited by: Schillberg S. Germany: Wiley-VCH Verlag; 2004: I I3-1 33.

18. Daniell H, Cohill PR, Kumar S, Dufourmantel N: Chloroplast Genetic Engineering. In Molecular Biology and Biotechnology of Plant Organelles Edited by: Daniell H, Chase CD. Netherlands: Springer Publishers; 2004:443-490.

19. Dufourmantel N, Pelissier B, Garçon F, Peltier JM, Tissot G: Generation of fertile transplastomic soybean. Plt Mol Biol 2004, 55:479-89.

20. Kumar S, Dhingra A, Daniell H: Plastid expressed betaine aldehyde dehydrogenase gene in carrot cultured cells, roots and leaves confers enhanced salt tolerance. Plt Physiol 2004, 136:2843-2854.

21. Kumar S, Dhingra A, Daniell H: Stable transformation of the cotton plastid genome and maternal inheritance of transgenes. Plt Mol Biol 2004, 56:203-2I6.

22. Daniell H, Kumar S, Duformantel N: Breakthrough in chloroplast genetic engineering of agronomically important crops. Trends Biotechnol 2005, 23:238-245.

23. Maier RM, Schmitz-Linneweber C: Plastid genomes. In Molecular Biology and Biotechnology of Plant Organelles Edited by: Daniell H, Chase CD. Netherlands: Springer publishers; 2004: II 15 - 50.

24. Ruf S, Hermann M, Berger I, Carrer H, Bock R: Stable genetic transformation of tomato plastids and expression of a foreign protein in fruit. Nat Biotechnol 200I, 19:870-875.

25. Llewellyn D, Fitt G: Pollen dispersal from two field trials of transgenic cotton in the Namoi valley, Australia. Mol Breeding 1996, 2:157-166.

26. Soltis DE, Soltis PS, Endress PK, Chase MW: Phylogeny and evolution of Angiosperms Sunderland Massachusetts: Sinauer Associates Inc; 2005.

27. Leebens-Mack J, Raubeson LA, Cui L, Kuehl J, Fourcade M, Chumley $\mathrm{T}$, Boore JL, Jansen RK, dePamphilis CW: Identifying the basal angiosperms in chloroplast genome phylogenies: Sampling one's way out of the Felsenstein zone. Mol Biol Evol 2005 , 22:1948-1963.

28. Goremykin VV, Hirsch-Ernst KI, Wolfl S, Hellwig FH: The chloroplast genome of Nymphaea alba: whole-genome analyses and the problem of identifying the most basal angiosperm. Mol Biol Evol 2004, 21 : | 445- I 454.

29. Goremykin VV, Hirsch-Ernst KI, Wolfl S, Hellwig FH: Analysis of the Amborella trichopoda chloroplast genome sequence suggests that Amborella is not a basal angiosperm. Mol Biol Evol 2003, 20:1499-1505.

30. Soltis DE, Albert VA, Savolainen V, Hilu K, Qiu Y-Q, Chase MW, Farris JS, Stefanoviæ S, Rice DW, Palmer JD, Soltis PS: Genome-scale data, angiosperm relationships, and 'ending incongruence': a cautionary tale in phylogenetics. Trends Plant Sci 2004, 9:477-483. 
31. Wolf PG, Rowe CA, Hasebe M: High levels of RNA editing in a vascular plant chloroplast genome: analysis of transcripts from the fern Adiantum capillus-veneris. Gene 2004, 339:89-97.

32. Kugita M, Yamamoto Y, Fujikawa T, Matsumoto T, Yoshinaga K: RNA editing in hornwort chloroplasts makes more than half the genes functional. Nucl Acids Res 2003, 3 I:24 I 7-2423.

33. Drescher A, Ruf S, Calsa T Jr, Carrer H, Bock R: The two largest chloroplast genome-encoded open reading frames of higher plants are essential genes. Plt / 2000, 22:97-104.

34. Sidorov VA, Kasten D, Pang SZ, Hajdukiewicz PT, Staub JM, Nehra NS: Technical advance: stable chloroplast transformation in potato: use of green fluorescent protein as a plastid marker. Plant J 1999, 19:209-216.

35. Nguyen TT, Nugent G, Cardi T, Dix PJ: Generation of homoplasmic plastid transformants of a commercial cultivar of potato (Solanum tuberosum L.). Plt Sci 2005, I 68: I 495-I 500.

36. McBride KE, Svab Z, Schaaf DJ, Hogan PS, Stalker DM, Maliga P: Amplification of a chimeric Bacillus gene in chloroplasts leads to an extraordinary level of an insecticidal protein in tobacco. BioTechn 1995, I3:362-365.

37. Kota M, Daniel H, Varma S, Garczynski SF, Gould F, William MJ: Overexpression of the Bacillus thuringiensis (Bt) Cry2Aa2 protein in chloroplasts confers resistance to plants against susceptible and Bt-resistant insects. Proc Natl Acad Sci USA 1999 96: | $840-1845$

38. lamtham S, Day A: Removal of antibiotic resistance genes from transgenic tobacco plastids. Nat Biotechnol 2000, I8: I I72-I I 76.

39. DeGray G, Rajasekaran K, Smith F, Sanford J, Daniell H: Expression of an antimicrobial peptide via the chloroplast genome to control phytopathogenic bacteria and fungi. Plant Physiology 200I, I 27:852-862

40. Molina A, Herva-Stubbs S, Daniell H, Mingo-Castel AM, Veramendi J: High yield expression of a viral peptide animal vaccine in transgenic tobacco chloroplasts. Plt Biotechnol ] 2004, 2: | 4 | - I 53.

41. Koya V, Moayeri M, Leppla SH, Daniell H: Plant based vaccine: mice immunized with chloroplast-derived anthrax protective antigen survive anthrax lethal toxin challenge. Infection and Immunity 2005, 73:8266-8274.

42. Watson J, Koya V, Leppla SH, Daniell H: Expression of Bacillus anthracis protective antigen in transgenic chloroplasts of tobacco, a non-food/feed crop. Vaccine 2004, 22:4374-4384.

43. Staub JM, Garcia B, Graves J, Hajdukiewicz PTJ, Hunter P, Nehra N: High-yield production of a human therapeutic protein in tobacco chloroplasts. Nat Biotechnol 2000, I 8:333-338

44. Fernandez-San Millan A, Mingo-Castel A, Miller M, Daniell H: A chloroplast transgenic approach to hyper express and purify human serum albumin, a protein highly susceptible to proteolytic degradation. Plt Biotechn J 2003, I:71-79.

45. Grevich JJ, Daniell H: Chloroplast genetic engineering: Recent advances and future perspectives. Crit Rev Plt Sci 2005 , 24:83-108.

46. Leelavathi S, Gupta N, Maiti S, Ghosh A, Reddy VS: Overproduction of an alkali-and thermo-stable xylanase in tobacco chloroplasts and efficient recovery of the enzyme. Mol Breed 2003, I I:59-67.

47. Guda C, Lee SB, Daniell H: Stable expression of biodegradable protein based polymer in tobacco chloroplasts. Plt Cell Rep 2000, 19:257-262.

48. Vitanen PV, Devine AL, Kahn S, Deuel DL, Van-Dyk DE, Daniell H Metabolic engineering of the chloroplast genome using the $E$. coli ubiC gene reveals that corismate is a readily abundant precursor for 4-hydroxybenzoic acid synthesis in plants. Plt Phys 2004, I 36:4048-4060.

49. Cosner ME, Jansen RK, Palmer JD, Downie SR: The highly rearranged chloroplast genome of Trachelium caeruleum (Campanulaceae): Multiple inversions, inverted repeat expansion and contraction, transposition, insertions/deletions, and several repeat families. Curr Genet 1997, 3 1:419-429.

50. Milligan BG, Hampton JN, Palmer JD: Dispersed repeats and structural reorganization in subclover chloroplast DNA. Mol Biol Evol 1989, 6:355-368.

5I. Maul JE, Lilly JW, Cui L, dePamphilis CW, Miller W, Harris EH, Stern DB: The Chlamydomonas reinhardtii plastid chromosome: Islands of genes in a sea of repeats. The Plant Cell 2002, I 4:1-22.

52. Pombert J-F, Otis C, Lemieux C, Turmel M: The chloroplast genome sequence of the green alga Pseudendoclonium akine- tum (Ulvophyceae) reveals unusual structural features and new insights into the branching order of chlorophyte lineages. Mol Biol Evol 2005, 22:1903-1918.

53. Schmitz-Linneweber C, Regel R, Du TG, Hupfer H, Herrmann RG Maier RM: The plastid chromosome of Atropa belladonna and its comparison with that of Nicotiana tabacum: the role of RNA editing in generating divergence in the process of plant speciation. Mol Biol Evol 2002, I9:1602-I6I2.

54. Hirose T, Kusumegi T, Tsudzuki T, Sugiura M: RNA editing sites in tobacco chloroplast transcripts: editing as a possible regulator of chloroplast RNA polymerase activity. Mol Gen Genet 1999, 262:462-467.

55. Fiebig A, Stegemann S, Bock R: Rapid evolution of RNA editing sites in a small non-essential plastid gene. Nucl Acids Res 2004 32:3615-3622.

56. Monde RA, Schusterc G, Stern DB: Processing and degradation of chloroplast mRNA. Biochimie 2000, 82:573-582.

57. Rochaix JD: Posttranscriptional control of chloroplast gene expression. From RNA to photosynthetic complex. Plt Phys 200I, I 25: |42-144.

58. Chang C-C, Lin H-C, Lin I-P, Chow T-Y, Chen H-H, Chen W-H, Cheng C-H, Lin C-Y, Liu S-M, Chang C-C, Chaw S-M: The chloroplast genome of Phalaenopsis aphrodite (Orchidaceae): Comparative analysis of evolutionary rate with that of grasses and its phylogenetic implications. Mol Biol Evol in press.

59. Soltis DE, Soltis PS, Chase MW, Mort ME, Albach DC, Zanis M, Savolainen V, Hahn WJ, Hoot SB, Fay MF, Axtell M, Swensen SM, Prince LM, Kress WJ, Nixon KC, Farris JS: Angiosperm phylogeny inferred from I 8S rDNA, rbcL, and atpB sequences. Bot J Linn Soc 2000, I33:381-46I

60. Savolainen V, Chase MW, Morton CW, Soltis DE, Bayer C, Fay MF de Bruijn A, Sullivan S, Qiu Y-L: Phylogenetics of flowering plants based upon a combined analysis of plastid atpB and $r b c L$ gene sequences. Syst Biol 2000, 49:306-362.

6I. Savolainen V, Fay MF, Albach DC, Backlund A, van der Bank M, Cameron KM, Johnson SA, Lledo MD, Pintaud J-C, Powell M, Sheahan MC Soltis DE, Soltis PS, Weston P, Whitten MW, Wurdack J, Chase MW Phylogeny of eudicots: a nearly complete familial analysis based on rbcL gene sequences. Kew Bull 2000, 55:257-309.

62. Sandbrink JM, Vellekoop P, Vanham R, Vanbrederode J: A method for evolutionary studies on RFLP of chloroplast DNA, applicable to a range of plant species. Biochem Syst Ecol 1989, I 7:45-49.

63. Jansen RK, Raubeson LA, Boore JL, dePamphilis CW, Chumley TW, Haberle RC, Wyman SK, Alverson AJ, Peery R, Herman SJ, Fourcade HM, Kuehl JV, McNeal JR, Leebens-Mack J, Cui L: Methods for obtaining and analyzing chloroplast genome sequences. Methods in Enzymology 2005, 395:348-384.

64. Sutton GG, White O, Adams MD, Kerlavage AR: TIGRAssembler: A new tool for assembling large shotgun sequencing projects. Gen Sci Techn 1995, I:9-19.

65. Pop M, Kosack DS, Salzberg SL: Hierarchical scaffolding with bambus. Gen Res 2004, I4: | 49-159.

66. Wyman SK, Boore JL, Jansen RK: Automatic annotation of organellar genomes with DOGMA. Bioinformatics 2004 , 20:3252-3255.

67. Kurtz S, Choudhuri JV, Ohlebusch E, Schleiermacher C, Stoye J, Giegerich R: REPuter: the manifold applications of repeat analysis on a genomic scale. Nucl Acids Res 2001, 29:4633-4642.

68. Higgins DG, Thompson JD, Gibson TJ: Using CLUSTAL for multiple sequence alignments. Meth Enzy 1996, 266:383-402.

69. Swofford DL: PAUP*: Phylogenetic analysis using parsimony (*and other methods), ver. 4.0 Sunderland MA: Sinauer Associates; 2003.

70. Hasegawa M, Kishino H, Yano T: Dating of the human-ape splitting by a molecular clock of mitochondrial DNA. J Mol Evol 1985, 22:160-174.

7I. Felsenstein J: Confidence limits on phylogenies: an approach using the bootstrap. Evolution 1985, 39:783-791.

72. Wakasugi T, Tsudzuki J, Ito S, Nakashima K, Tsudzuki T, Sugiura M: Loss of all ndh genes as determined by sequencing the entire chloroplast genome of the black pine Pinus thunbergii. Proc Natl Acad Sci USA 1994, 9 I:9794-9798.

73. Hiratsuka J, Shimada H, Whittier R, Ishibashi T, Sakamoto M, Mori M, Kondo C, Honji Y, Sun CR, Meng BY, Li YQ, Kanno A, Nishizawa Y, Hirai A, Shinozaki K, Sugiura M: The complete sequence of the rice (Oryza sativa) chloroplast genome: intermolecular 
recombination between distinct tRNA genes accounts for a major plastid DNA inversion during the evolution of the cereals. Mol Gen Genet 1989, 2 I 7:185-194.

74. Asano T, Tsudzuki T, Takahashi S, Shimada H, Kadowaki K: Complete nucleotide sequence of the sugarcane (Saccharum officinarum) chloroplast genome: a comparative analysis of four monocot chloroplast genomes. DNA Res 2004, I I:93-99.

75. Maier RM, Neckermann K, Igloi GL, Kossel H: Complete sequence of the maize chloroplast genome: gene content, hotspots of divergence and fine tuning of genetic information by transcript editing. J Mol Biol 1995, 25 I:614-628.

76. Goremykin VV, Hirsch-Ernst KI, Wolfl S, Hellwig FH: The chloroplast genome of the "basal" angiosperm Calycanthus fertilis structural and phylogenetic analyses. Plt Syst Evol 2003, 242: II9-135.

77. Sato S, Nakamura Y, Kaneko T, Asamizu E, Tabata S: Complete structure of the chloroplast genome of Arabidopsis thaliana. DNA Res 1999, 6:283-290.

78. Steane DA: Complete nucleotide sequence of the chloroplast genome from the Tasmanian blue gum, Eucalyptus globulus (Myrtaceae). DNA Res 2005, I 2:215-220.

79. Kato T, Kaneko T, Sato S, Nakamura Y, Tabata S: Complete structure of the chloroplast genome of a legume, Lotus japonicus. DNA Res 2000, 7:323-330.

80. Shinozaki K, Ohme M, Tanaka M, Wakasugi T, Hayashida N, Matsubayashi T, Zaita N, Chunwongse J, Obokata J, Yamaguchi-Shinozaki K, Ohto C, Torazawa K, Meng BY, Sugita M, Deno H, Kamogashira T, Yamada K, Kusuda J, Takaiwa F, Kato A, Tohdoh N, Shimada H, Sugiura $M$ : The complete nucleotide sequence of the tobacco chloroplast genome: its gene organization and expression. EMBO J 1 986, 5:2043-2049.

8I. Hupfer H, Swaitek M, Hornung S, Herrmann RG, Maier RM, Chiu WL, Sears B: Complete nucleotide sequence of the Oenothera elata plastid chromosome, representing plastome I of the five distinguishable Euoenthera plastomes. Mol Gen Genet 2000, 263:58I-585.

82. Kim K-J, Lee H-L: Complete chloroplast genome sequence from Korean Ginseng (Panax schiseng Nees) and comparative analysis of sequence evolution among $I 7$ vascular plants. DNA Res 2004, I I:247-26I.

83. Schmitz-Linneweber C, Maier RM, Alcaraz JP, Cottet A, Herrmann RG, Mache R: The plastid chromosome of spinach (Spinacia oleracea): complete nucleotide sequence and gene organization. Plt Mol Biol 200I, 45:307-3I5.

84. Palmer JD: Chloroplast DNA exists in two orientations. Nature 30I:92-93.

85. APG II: An update of the Angiosperm Phylogeny Group classification for the orders and families of flowering plants: APG II. Bot J Linn Soc 2003, I 41:399-436.
Publish with Bio Med Central and every scientist can read your work free of charge

"BioMed Central will be the most significant development for disseminating the results of biomedical research in our lifetime. "

Sir Paul Nurse, Cancer Research UK

Your research papers will be:

- available free of charge to the entire biomedical community

- peer reviewed and published immediately upon acceptance

- cited in PubMed and archived on PubMed Central

- yours - you keep the copyright
BioMedcentral 